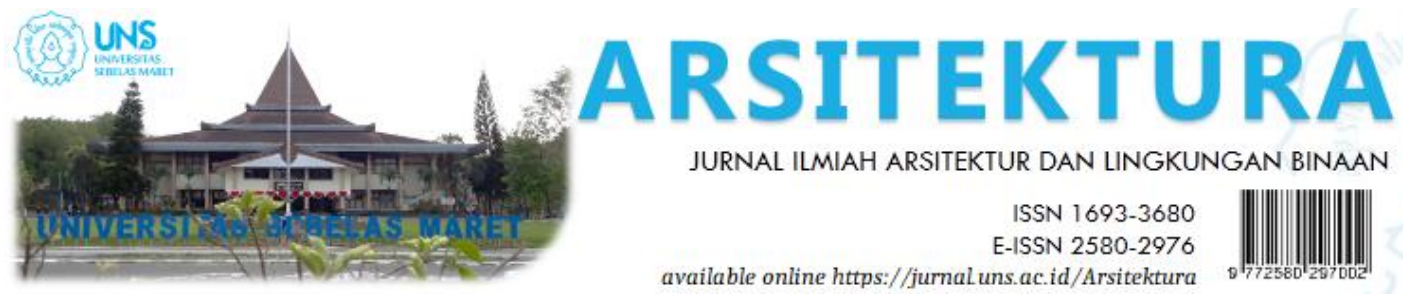

Volume 18 Issue 2 October 2020, pages:315-326

\title{
Penerapan Konsep A.B.L.E. Pada Ruang Terapi Anak Berkebutuhan Khusus Cerebral Palsy
}

\section{The Application of A.B.L.E. Concept at Children's Therapy Room with Special Needs Cerebral Palsy}

\author{
Andreas Dwiputro Handoyo ${ }^{1 *}$, Widyanesti Liritantri ${ }^{2}$, Mutiara Dhya Ulhaq Pramesi ${ }^{3}$, Allicia \\ Sandra Meirissa ${ }^{4}$ \\ Prodi Desa in Interior, Fakultas Industri Krea tif, Universitas Telkom Bandung ${ }^{1 *}$ \\ ashandoyo@ telkomuniversity.ac.id \\ ProdiDesain Interior, Fa kultas Industri Kreatif, Universitas Telkom Bandung ${ }^{2}$ \\ ProdiDesain Interior, Fa kultas Industri Kreatif, Universitas Telkom Bandung ${ }^{3}$ \\ ProdiDesain Interior, Fa kultas Industri Kreatif, Universitas Telkom Bandung ${ }^{4}$
}

DOI: https://doi.org/10.20961/arst.v18i2.43680

Received: August 11,2020 Revised: October 20, 2020 Accepted:October 21, 2020 Available online: October 31, 2020

\begin{abstract}
Cerebral Palsy is a condition characterized by poor muscle control, stiffness, paralysis, to other nerve disorders. These children are at the highest level of priority among children with special needs. Helping children with Cerebral Palsy can be realized through the design of a special therapy centre for children with Cerebral Palsy. The design of this therapy centre will be specified in the design concept of the play therapy room because in this case, the playground works as well as therapeutic method for children. This study was conducted using qualitative descriptive analytical methods in Risantya facility which applies play as a therapeutic approach. The observation focused on the activities of the children in the playground. It was found that four factors play an important role in the therapy area. A.B.L.E. has meaning, namely A for Attractive Colours, B for Bump, Bruise, and Pain-Free, Lfor Low Physical Effort, and E for Engaged positively with movement. The concept is described to therapy centre, especially in the play therapy room, where this concept aims to provide a sense of ease, safety, and comfortto children when doing activities.
\end{abstract}

Keywords: interior design, play therapy, cerebral palsy, therapy center

\section{PENDAHULUAN}

Menurut Kementrian Pemberdayaan Perempuan dan Perlindungan Anak Republik Indonesia dalam buku Menemukenali Dan Menstimulasi Anak Penyandang Disabilitas (Nurakhmi, et. al., 2019) terdapat delapan kategori dari disabilitas yang salah satunya adalah kategori disabilitas fisik. Disabilitas fisik adalah kehilangan (keseluruhan atau sebagian) dari fungsi tubuh dalam kegiatan motorik (bergerak) seperti berjalan, motorik halus, berbicara, pergerakan tangan dan lainlain. Dalam kategori fisik ini terdapat beberapa gangguan pada anak salah satunya disebut Cerebral Palsy. Cerebral Palsy atau dapat 
disingkat $\mathrm{CP}$ adalah suatu keadaan yang ditandai dengan buruknya pengendalian otot, kekakuan, kelumpuhan, keterampilan motorik (kemampuan untuk bergerak dalam cara yang terkoordinasi atau terarah) dan gangguan fungsi saraf lainnya. CP biasanya disebabkan oleh kerusakan otak yang terjadi sebelum atau selama kelahiran anak (Kristiawan, et al., 2016). CP juga terbagi menjadi beberapa kategori atau klasifikasi berdasar kelainan geraknya, yaitu Spastik, Atetoid/ Diskinetik, Ataksid, Campuran (Moeloek, 2018). Selain kategori berdasar kelainan gerak, penderita $\mathrm{CP}$ dibagi lagi berdasar kemampuan motorik kasar atau GMFCS (Gross Motor Function Classification System), yaitu dari level satu hingga level lima. Semakin tinggi angkanya maka semakin tidak memungkinkannya anak dapat bergerak, sehingga anak sangat membutuhkan bantuan dari orang lain (Probowati dan Saing, 2019)

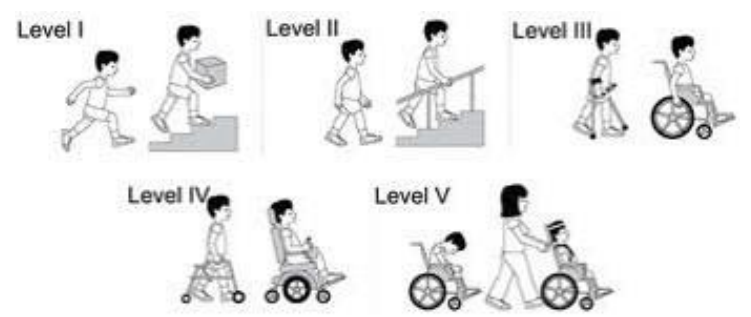

Gambar 1. Gross Motor Function Classification System

Sumber: Probowati dan Saing, 2019.

Menurut data dari Riskesdas berdasar pada tahun 2010 dan 2013 prevalensi kecacatan anak penyandang CP dengan umur 24-59 bulan di Indonesia adalah $0,09 \%$ Hal tersebut menunjukkan bahwa pravelansi $\mathrm{CP}$ di Indonesia menunjukan jumlah yang besar bahwa terdapat sembilan kasus dalam setiap 1.000 kelahiran (Diono, 2014). Cerebral Palsy dengan ketunadaksaan terjadi di Indonesia pada tahun 2018 dengan jumlah penduduk di Indonesia dengan disabilitas mencapai 2.126.000 jiwa, dengan total jumlah CP sedang 717.312 dan CP berat 149.458 jiwa, sama dengan menyumbang angka $47,4 \%$ dari keseluruhan jumlah difabel.

Berdasarkan data di atas dapat dikatakan bahwa anak penyandang $\mathrm{CP}$ membutuhkan penanganan dan perhatian khusus untuk menunjang kehidupannya menjadi lebih baik dan optimal. Keterbatasan yang dialami penderita $\mathrm{CP}$ membuat anak tidak dapat memenuhi kebutuhannya sendiri dan harus mendapatkan bantuan dari orang lain (Graham, et al., 2016). Namun saat ini penanganan anak penyandang $\mathrm{CP}$ nyatanya masih belum dilakukan secara komprehensif. Bantuan orang tua saja tenyata belum cukup untuk menunjang kehidupan anak penyandang $\mathrm{CP}$ karena masih perlunya edukasi khusus bagi orang tua atau keluarga dalam menangani keseharian anak penyandang $\mathrm{CP}$. Pada keadaan ini maka perlunya kerja sama dari para ahli untuk perkembangan anak CP. Dalam aspek perkembangan untuk menemukenali anak dengan $\mathrm{CP}$ harus melibatkan ahli yang memahami tumbuh kembang dan gangguan perkembangan anak, misalnya dokter anak, saraf anak atau psikolog, karena membutuhkan pemeriksaan yang lebih komprehensif (Nurakhmi, et. al., 2019).

Untuk membantu dan memperjuangkan anak penyandang $\mathrm{CP}$ dapat diwujudkan melalui perancangan sebuah pusat terapi khusus untuk anak penyandang CP. Pusat terapi ini akan menjadi media komunikasi, terapi, serta pengetahuan bagi banyak pihak utamanya bagi keluarga dan anak penyandang CP. Dengan adanya pusat terapi ini diharapkan dapat membantu dan menangani pasien secara lebih baik dan optimal. Tujuan terapi bagi pasien ini adalah membantu dirinya dan pihak keluarganya dalam memperbaiki fungsi motorik dan mencegah deformitas serta penyesuaian emosional dan pendidikan sehingga penderita sedikit mungkin memerlukan pertolongan orang lain dan diharapkan penderita bisa mandiri dalam melakukan aktivitas kehidupannya di kemudian hari (AHP, 2013).

Edukasi juga diperlukan untuk mengajarkan dan menginformasikan kepada keluarga untuk melatih anak dengan teratur dan dukungan moral kasih sayang di rumah agar anak lebih cepat mandiri (Purnomo, Kuswardani, dan Novitasari, 2018). Perawatan yang dapat dilakukan di pusat terapi meliputi terapi fisik, terapi okupasi, hydrotherapy, wicara dan lainlain. Dari adanya jenis-jenis perawatan untuk anak $\mathrm{CP}$, maka diperlukannya desain fasilitas dan ruang yang mendukung terjalankannya jenis-jenis perawatan tersebut.

Salah satu jenis fasilitas ruang yang dapat diaplikasikan menurut pendekatan aktivitas dan 
perilaku adalah ruang bermain yang dapat digunakan sebagai terapi bermain atau play therapy. Perry dan Szalavitz (2006) menyatakan bahwa aktivitas bermain adalah hal mendasar dari anak-anak, hal ini sangat penting untuk perkembangan holistik anak-anak. Saat anak terlibat dalam proses permainan, terapis maupun orang tua dapat bergabung dalam pengalaman anak dan mendapatkan pemahaman tentang persepsi anak tentang diri, orang lain, dan dunia (Bratton dan Dafoe, 2016; Glover, 2015). Dengan begitu terapis lebih mudah untuk melakukan terapi kepada anak karena adanya proses pemahaman yang dilakukan saat bermain.

Pemenuhan kebutuhan ruang yang sesuai dengan fungsi, kondisi pengguna dan tujuan metode terapi yang diterapkan memberikan pengaruh positif pada perkembangan anak (Sari, 2011). Berdasarkan hal tersebut maka pemilihan suatu pendekatan desain dapat menjadi salah satu cara dalam menentukan konsep desain ruang dan fasilitas yang sesuai dengan kebutuhan dan memberikan dampak positif anak, orang tua, dan terapis.

Pendekatan aktivitas dan perilaku diaplikasikan untuk mendukung terciptanya konsep desain dan fasilitas yang sesuai dengan pusat terapi anak CP. Pendekatan ini akan berpacu pada aktivitas dan perilaku user atau pengguna di dalam ruangan sehingga menciptakan suasana ruang yang kondusif bagi pengguna sesuai dengan konsep desain yang diaplikasikan. Salah satu contoh tempat terapi anak CP dengan metode permainan adalah Sekolah dan Tempat Terapi Anak Berkebutuhan Khusus Risantya yang terletak di Kota Bandung, Jawa Barat.

Secara umum Risantya menangani terapi bagi Anak Berkebutuhan Khusus (ABK) secara umum, tetapi juga bagi anak-anak penyandang CP (Handoyo, et.al., 2020). Ada tiga fasilitas yang digunakan dalam memenuhi latihan dasar terapi anak $\mathrm{CP}$ yang berbeda-beda sesuai dengan jenis terapinya; fisioterapi, sensori integrasi, dan terapi bermain. Fasilitas fisioterapi untuk untuk melatih motorik tangan dan kaki anak. Tahap selanjutnya, terapi sensori integrasi untuk melatih koordinasi motorik tangan dan kaki, suatu proses mengenal, mengubah, dan membedakan sensasi dari sistem sensori untuk menghasilkan suatu respon. Terapi bermain dilakukan untuk melatih anak penyandang $\mathrm{CP}$ dalam berkomunikasi, berlatih motorik, seperti berdiri, berjalan, dan sensor badan. Meskipun berbeda dalam penamaan ruangan, pada dasarnya semua pelatihan dan terapi yang dilakukan menggunakan alat-alat permainan sehingga anak-anak dapat menikmati.

Penelitian ini merupakan studi lanjutan dari penelitian sebelumnya tentang faktor yang menjadi prioritas utama pada perancangan interior tempat terapi. Proses tumbuh kembang anak, aktivitas dan perilaku anak CP ini akan terpengaruh dengan interior yang ada di tempat terapi, salah satunya warna pada interior. Sarihati \& Ardini, (2017) menyatakan bahwa pada banyak penelitian mengenai kerterkaitan warna dengan kehidupan manusia, diperoleh hasil bahwa penggunaan warna dapat mempengaruhi jiwa dan emosi manusia serta mempengaruhi kegiatan fisik dan mental. Penggunaan warna cerah asal tidak berlebihan dapat memberikan suasana khas anak-anak yang dapat menimbulkan rasa betah di ruangan. Bagi anak hiposensitif, warna cerah atau yang bernuansa hangat diperlukan untuk merangsang reaksi inderanya (Astuti, 2018). Selain itu warna juga berpengaruh terhadap kreativitas dan kenyamanan fisik (Astarina, 2012) dalam halnya warna merah yang berhubungan dengan emosional yang dapat meningkatkan metabolism dan respirasi, oranye dapat meningkatkan oksigen ke otak dan merangsang aktivitas mental, kuning dapat merangsang sistem saraf, hijau warna untuk meringankan stress, biru dapat membantu konsentrasi, coklat natural kayu membangkitkan perasaan hubungan dengan bumi, dan menawarkan rasa ketertiban, serta putih untuk memurnikan dan menyempurnakan sistem energi. Warna juga dapat digunakan sebagai wayfinding. Wayfinding merupakan suatu proses bagaimana manusia bernavigasi dan berorientasi diri dalam suatu ruang (Malaria and Schools, 2010). Warna dan wayfinding selalu merupakan komponen desain (layanan kesehatan) yang penting, tetapi khususnya untuk pasien yang kemampuan fisik dan kognitifnya mungkin terganggu (Phillips, 2015). Termasuk signage dan atau petunjuk arah yang disajikan dalam banyak modalitas, warna, bahasa, dan simbol, sehingga pengguna/ anak dapat lebih mudah membaca dan memproses informasi.

Selain warna, material juga akan berpengaruh terhadap aktivitas dan perilaku anak. Material 
yang digunakan harus berdurabiliti tinggi dan aman untuk anak - anak (Sakya dan Santosa, 2016). Material yang dipilih harus memudahkan khususnya dalam hal keamanan (safety) dan perawatan, baik dalam area tetapi maupun area umum lainnya. Beberapa diantaranya adalah dinding vinyl, parket, linoleum, karpet, gypsum board, HPL, akrilik, acoustic wall (Sakya dan Santosa, 2016). Pada penggunaan material pada dinding hindari penggunaan material ataupun cat yang mudah menguap atau terdapat kandungan VOCS (Volatile Organic Compounds) (Philips, 2015). Lapisan penutup dinding harus bersifat non porosif (tidak mengandung pori-pori) sehingga dinding tidak dapat menyimpan debu. Material yang baik akan mendukung proses terapi anak serta menjaga anak untuk tetap aman dan nyaman selama proses terapi.

Nielson dan Taylor (2011) berpendapat bahwa elemen desain meliputi ruang, bentuk, massa, garis, tekstur, pola, cahaya, dan warna yang digunakan oleh setiap desainer dalam setiap disiplin. Dalam hal ini elemen bentuk memiliki pengaruh terhadap tempat terapi anak. Karakteristik pada CP memiliki beberapa kesamaan dengan autis, yaitu perilaku yang tidak terkontrol dan susah fokus maka pengaplikasian bentuk dapat saling berhubungan (Susanto dan Kristianto, 2016). Mengingat anak dengan ganguan autis sangat sensitif hingga dapat menyebabkan tantrum, maka perlu memperhatikan juga hal seperti bentuk dan properti yang ada di sekeliling. Benda atau properti yang ada haruslah yang bersifat ramah/aman. Benda yang dimaksud adalah segala elemen dan atribut interior yang tidak runcing/tidak tajam, benda yang lembut/lunak/tidak berbahaya apabila terjadi benturan dan tidak akan melukai anak (Aflah dan Anisa, 2020). Penggunaan bentuk sederhana memang tidak memberi stimuli berlebihan pada anak namun terlalu lembut juga tidak merangsang kreativitas mereka. Kemudian untuk mendapatkan proporsi juga skala yang berimbang, perlu dipertimbangkan juga dimensi ruang yang digunakan dan penggunanya (Sakya dan Santosa, 2016). Maka dari itu, penggunaan bentuk-bentuk dinamis dapat diaplikasikan dalam ruang untuk mendorong kreatifitas dan stimulus anak. Selain itu juga karena anak CP memiliki gangguan pada motoriknya sehingga sebagian menggunakan kursi roda, maka bentuk yang diaplikasikan pada furnitur atau fasilitas terapi harus dapat menyesuaikan $\mathrm{CP}$ yang menggunakan kursi roda. Hal ini diaplikasikan untuk memberikan kenyamanan dan keamanan bagi anak dalam melakukan aktivitasnya.

Melihat bahwa beberapa karakteristik anak CP dan autis memiliki kesamaan, maka dalam desain sirkulasi interior tempat terapi memiliki tujuan desain yang sama. Pertimbangan dalam membuat tata letak, faktor zonasi dan sirkulasi harus jelas, tidak membingungkan, efektif dan mudah dijangkau. Sirkulasi linier memiliki kriteria aman dan nyaman, karena arus sirkulasi jelas, sesuai dengan desain partisipasi yang mempertimbangkan kondisi pengguna (Triani, et al, 2018). Yang menjadi pembeda adalah bahwa perlunya memperhatikan sirkulasi untuk kursi roda karena $\mathrm{CP}$ memiliki gangguan motorik yang menyebabkan sebagian anak menggunakan kursi roda untuk mobilisasinya. Menurut Widi \& Nirwansyah (2013) sirkulasi untuk pengguna kursi roda minimal memiliki luasan area $152,4 \mathrm{~cm} \times 152,4 \mathrm{~cm}$. Hal ini memudahkan pengguna kursi roda untuk melakukan perputaran sehingga lebih leluasa dalam bergerak.

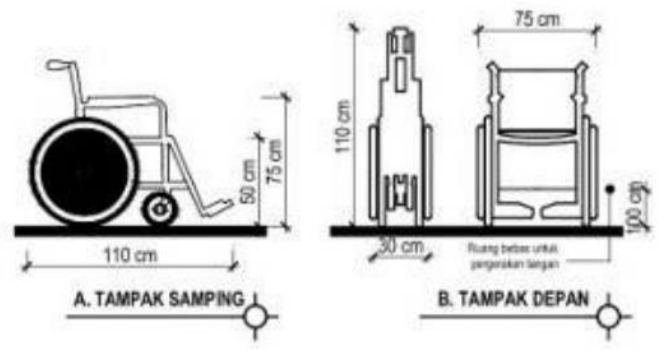

Gambar 2. Ukuran Kursi Roda

Sumber: Widi \& Nirwansyah, 2013.

Ergonomi dalam tempat terapi juga menjadi hal yang harus diperhatikan. Ilmu ergonomi digunakan untuk menggali, menerapkan informasi-informasi mengenai perilaku manusia, kemampuan, keterbatasan dan karakteristik manusia lainnya untuk merancang peralatan yang dibutuhkan dalam pekerjaan dan lingkungan guna meningkatkan produktivitas, keselamatan kenyamanan dan efektivitas pekerjaan manusia (Atin, et al, 2018). Ergonomi ini harus dapat membuat anak CP menggunakan upaya fisik yang rendah dalam melakukan aktivitasnya. Salah satu ergonomi yang penting diperhatikan untuk anak $\mathrm{CP}$ 
adalah penggunaan ramp dan handrail. Ramp dan handrail ini untuk mempermudah aksesibilitas, maka dari itu ergonomi yang digunakan harus tepat untuk membuat anak aman dan nyaman menggunakannya. Dalam mendesain sebuah ramp harus diperhatikan beberapa elemen, mulai dari handrail yakni pegangan yang ada di samping kanan kiri, hingga kemiringannya. Perlu diketahui bahwa kemiriangan dari ramp tidak boleh lebih dari tujuh derajat. Dan juga setiap $900 \mathrm{~cm}$ atau 9 meter dari panjang ramp tersebut perlu adanya tempat untuk istirahat (Kusuma \& Budiono, 2014). Bahan pegangan tangan harus terbuat dari bahan yang tahan api, mudah dibersihkan dan memiliki lapisan permukaan yang bersifat non-porosif (tidak mengandung poripori). Selain ergonomi, antropometri juga penting diperhatikan. Astuti (2019) menyebutkan bahwa antropometri dilakukan untuk mendapatkan dimensi atau ukuran produk yang sesuai dengan tubuh pemakai secara detail sehingga pengguna merasa nyaman ketika memakai produk tersebut, dalam hal ini anakanak. Antropometri ini harus dapat menyesuaikan pengguna kursi roda ataupun pengguna tongkat untuk membantu dalam melakukan aktivitas terapi. Antropometri yang baik dapat membuat anak $\mathrm{CP}$ dapat merasa nyaman dan aman dalam melakukan aktivitasnya.

Fasilitas tempat terapi umumnya dirancang khusus sesuai karakter penggunanya (Rea, 2013). Sama halnya dengan fasilitas terapi anak-anak dengan $\mathrm{CP}$ memiliki kebutuhan dengan tingkat tertinggi dibandingkan ABK lainnya. Oleh karena itu, fasilitas yang dirancang bagi penderita $\mathrm{CP}$ dapat dimanfaatkan oleh $\mathrm{ABK}$ dengan spektrum lain. Namun, hal ini tidak terjadi sebaliknya (Handoyo, et.al, 2020). Adanya penelitian ini diharapkan dapat membantu proses perencanaan dan perancangan fasilitas terapi dengan memerhatikan empat faktor yang prioritas untuk disiapkan dalam desain, tidak hanya berdampak positif bagi anak-anak tetapi juga terapis dan orang tua. Faktor ini tidak semata-mata diterapkan pada desain, nyatanya banyak faktor pertimbangan lain dari sisi psikologi dan lainnya dalam merancang tempat terapi.

Di sisi lain, penelitian ini membuka peluang untuk mengajak kolaborasi para praktisi dan akademisi lintas disiplin ilmu dalam menyusun panduan perancangan.

\section{METODE}

Penelitian ini dilakukan dengan metode kualitatif deskriptif analitis melanjutkan penelitian sebelumnya mengenai faktor prioritas dalam perancangan fasiltias terapi. Studi dari metode ini dilakukan di Sekolah dan Terapi Anak Berkebutuhan Khusus Risantya, Kota Bandung. Metode ini terdiri dari data primer yaitu observasi dan dokumentasi yang dilakukan dengan cara mengamati perilaku dan lingkungan interior area terapi, seperti lantai, dinding, plafon, juga atribut interior seperti alat terapi atau alat permainan yang digunakan untuk terapi. Observasi dilakukan pada hari Senin-Kamis antara pukul 09.00 - 13.00 saat pelaksanaan sekolah dan terapi di Risantya. Aktivitas anak penyandang CP yang diamati antara lain saat melakukan terapi.

Data lainnya yang digunakan yaitu wawancara kepada para terapis dan pengelola Risantya, yang berhubungan langsung dengan orang tua dan anak-anak untuk mendapatkan informasi mengenai respon anak $\mathrm{CP}$ terhadap interior ruang terapi, seperti respon anak pada bentuk dan warna yang ada di ruang terapi.

Selain itu terdapat data sekunder, yaitu studi literatur. Studi ini mengumpulkan data yang berasal dari jurnal, buku, serta pedoman standarisasi. Seperti penggunaan warna, sirkulasi, material, dan bentuk untuk mengetahui respon anak terhadap elemen ruang, serta studi tentang standar dan kebutuhan terapi anak CP untuk menganalisis desain ruang terapi yang baik untuk anak.

Hasil dari data-data tersebut yang dikumpulkan akan dianalisis dengan elemen interior yang ada di Terapi Anak Berkebutuhan Khusus Risantya sehingga akan menemukan hal-hal yang menjadi prioritas dalam desain tempat terapi anak, khususnya terapi anak CP.

\section{HASIL DAN PEMBAHASAN}

Untuk mengetahui hal-hal yang menjadi prioritas dalam mendesain tempat terapi yang tepat bagi anak penyandang $\mathrm{CP}$, maka dilakukanlah analisis dengan pendekatan aktivitas dan perilaku pada interior area terapi bermain. Bagaimana kondisi area terapi saat ini 
dalam mendukung proses terapi dan pengembangan anak $\mathrm{CP}$.

\subsection{Attractive Colors}

Warna menjadi sasaran utama yang diterapkan di Risantya karena dapat merangsang pemikiran kreatif dan kenyamanan bagi anak (Astarina, 2012). Pengaplikasian warna pada tempat terapi Risantya ini menggunakan warna cerah. Warna ini paling mudah terlihat pada bidang interior yang cukup besar, seperti dinding dan dinding. Kedua bidang ini paling prioritas untuk diolah karena lebih sesuai dengan antropometri pandangan anak-anak. Dengan begitu, area plafon meskipun sama pentingnya, tetapi tidak menjadi prioritas utama ketika ada proses renovasi. Warna pun dibiarkan putih ataupun warna ekspos dari material itu sendiri yang dapat menjadi penetral warna-warna cerah lainnya.

Ruang fisioterapi dan terapi sensori merupakan ruangan tersendiri yang dindingnya menggunakan kombinasi hijau dan kuning (lihat Gambar 3). Warna kuning ditempatkan pada bagian bawah agar menyesuaikan ketinggian jarak pandang anak-anak. Warna kuning yang dapat merangsang sistem saraf anak agar lebih aktif diimbangi oleh penggunaan warna hijau yang dapat menenangkan (Astuti, 2018; Whitfield, 1990).

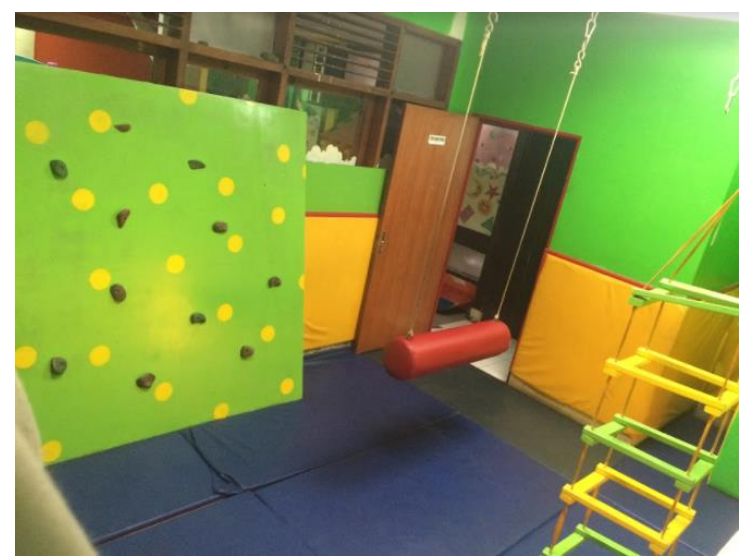

Gambar 3. Kombinasi Wa rna Hijau Kuning pada Area Terapi

Pada area bermain, warna justru didominasi nuansa warna coklat natural pada lantai keramik, warna netral pada bagian langit-langit, dan aksen berbagai warna di dinding. Kombinasi berbagai warna menjadi sasaran utama untuk meningkatkan pemikiran kreatif pada anak dan menimbulkan kenyamanan anak dari suasana yang diciptakan (Astarina, 2012).

Warna-warna cerah memang disarankan untuk merangsang kreativitas dan imajinasi serta memperkuat rangsangan motorik.

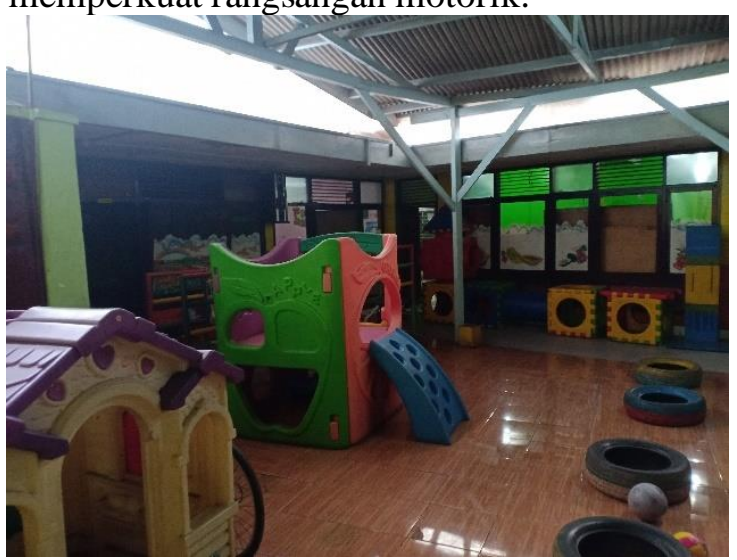

Gambar 4. Kombinasi Wa rna pada Area Bermain

Membandingkan studi warna yang ada dengan kondisi di Risantya, penerapan warna cerah sudah tepat diaplikasikan, karena warna ini akan membuat anak betah di ruangan, serta secara tidak langsung akan menstimulus anak dalam proses terapi. Namun, pada penggunaannya, warna cerah dan intensitasnya perlu diperhatikan agar tidak membuat masalah hiperaktifitas semakin menjadi (Sakya dan Santosa, 2016). Warna cerah yang diaplikasikan tidak ada penetral dari warna cerah yang dapat mengakibatkan anak terlalu hiperaktif dan tidak terkontrol. Maka dari itu, selain warna cerah, kombinasi warna netral seperti putih dan warna hangat seperti coklat kayu dapat dikombinasikan sebagai penetral warna dari ruang terapi. Maupun pemilihan warna dengan tingkat kecerahan lebih rendah, seperti warna-warna pastel.

Perlu diperhatikan juga bahwa dampak warna yang dirasakan akan dipengaruhi juga oleh penerapan pencahayaan di interior ruang. Area bermain termasuk area yang cukup terbuka dengan memaksimalkan pencahayaan alami dari kisi atap. Begitu pula dengan area ruang terapi lain yang meskipun menggunakan lampu, tetap mengupayakan penerangan alami. Hal ini dinilai agar warna yang dipakai dapat tampil apa adanya dan memberi dampak optimal kepada anak-anak. Penerapan warna secara umum, perlu mendapat kajian lebih mendalam tentang bagaimana dampaknya bagi anak-anak yang hiposensitif atau hipersensitif terhadap warna. 
Fungsi warna yang lain dapat digunakan sebagai wayfinding. Wayfinding memudahkan anak dalam melakukan orientasi di dalam ruang, dikarenakan jika menggunaskan tulisan sebagai tanda dapat membuat anak kesulitan dalam mengenalinya, maka dengan warna akan lebih mempermudah anak untuk 'membaca ' dengan mengenali warnanya. Pada tempat terapi Risantya, belum diaplikasikannya wayfinding untuk membuat anak lebih mandiri dan dapat belajar mengenali tanda. Maka hal ini menjadi salah satu hal yang harus diterapkan pada tempat terapi untuk membantu anak dalam meningkatkan stimulus dan respon. Kombinasi warna-warna cerah (hijau, merah, kuning, biru, dan orange) juga diaplikasikan pada alat/atribut terapi di Risantya, agar menarik anak-anak untuk tertarik beraktivitas ataupun terapi dengan alat tertentu.

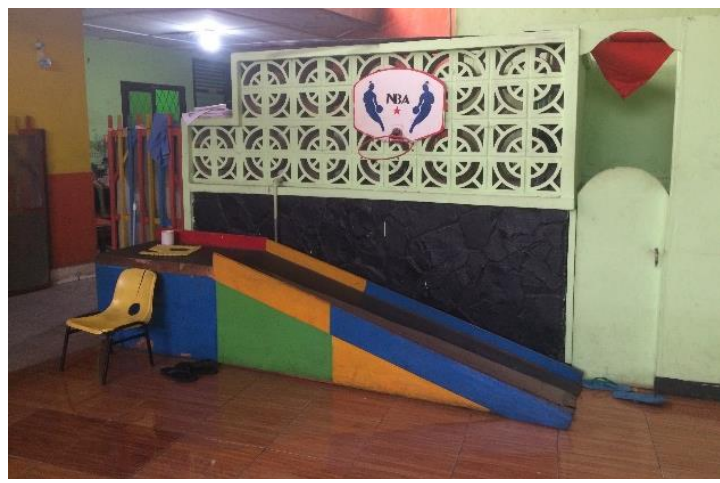

Gambar 5. Aplika si Warna pada Terapi Bermain

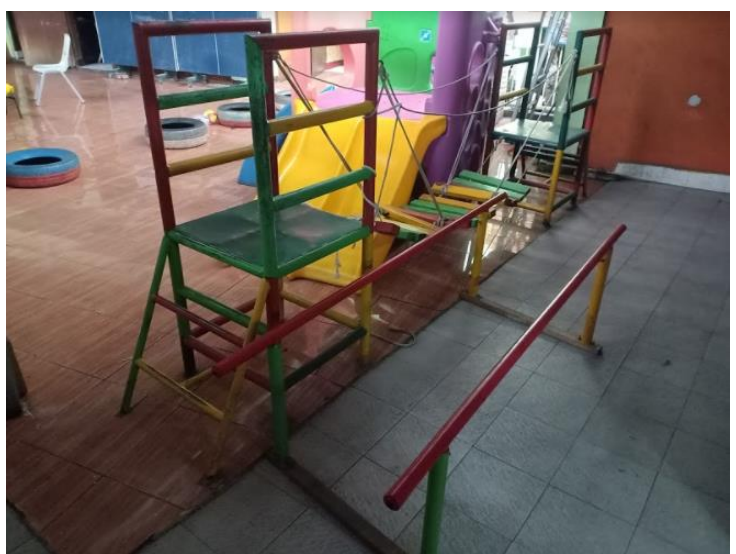

Gambar 6. Aplika si Warna pada Terapi Bermain

Aplikasi warna yang ada di Risantya otomatis menjadi penanda dengan adanya proses adaptasi dari setiap individu. Ada yang cepat ada pula yang lambat. Sejalannya dengan waktu, anak-anak dibiarkan mengidentifikasi warna-warna yang ada di sekitarnya dan mengenali benda-benda dengan warna tertentu.

\subsection{Bump, Bruise, and Pain-Free}

Penerapan material memiliki pengaruh jika diterapkan pada interior untuk anak berkebutuhan khusus yang memiliki sensitivitas tinggi terhadap lingkungan sekitarnya. Karena kekakuan otot, anak CP sering mengalami gerakan-gerakan yang tidak terkontrol sehingga berjalan seperti robot atau berjalan dengan menyeret salah satu kaki. Situasi ini harus menghindari bentukan runcing dan sudut tajam, serta bentukan ruang terapi harus menarik namun tetap aman untuk digunakan oleh anak-anak CP (Susanto dan Kristianto, 2016).

Pada studi observasi di Risantya, beberapa bentuk furnitur dan alat terapi masih memiliki bentuk yang bersudut tajam (lihat gambar 7) sehingga anak-anak harus diawasi ketika bermain maupun saat terapi. Bentuk tajam ini terlihat pada furnitur di ruang fisioterapi dan terapi motorik. Bentuk runcing ini baiknya diganti dengan bentukan yang tumpul untuk membuat anak lebih aman.
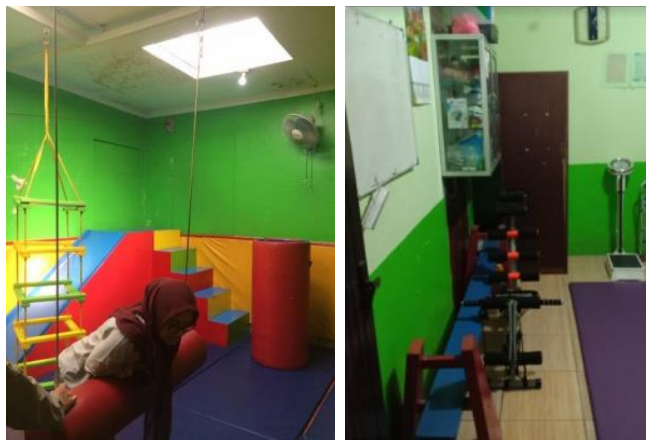

Gambar 7. Sudut Tajam pada Ruang Terapi

Sensori (kiri) dan Fisioterapi (kanan)

Aflah \& Anisa (2020) menambahkan dalam pemilihan material sangat dianjurkan material yang bersifat sehat. Hal yang dimaksud adalah material yang aman dan mudah dibersihkan. Ruang terapi perlu menjamin keselamatan anak-anak agar terhindar dari luka akibat benturan dengan benda atau elemen interior yang ada sekitarnya saat melakukan terapi.

Pada tempat terapi Risantya, ruang terapi bermain menggunakan penutup lantai keramik yang memiliki risiko tinggi jika anak terjatuh karena material ini cukup licin (lihat Gambar 8).Material ini tidak direkomendasikan 
penerapannya pada ruang terapi. Penggunaan lantai vinyl atau karpet lebih aman, nyaman, dan dapat mengurangi risiko cedera pada anak CP (Sakya dan Santosa, 2016). Pada ruang motorik, lantai sudah dilapis oleh busa sebagai bentuk keamanan (safety) saat anak melatih motorik gerak tubuhnya.

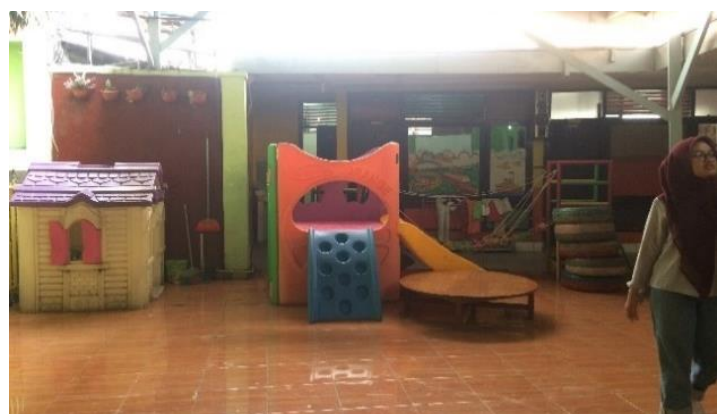

Gambar 8. Penerapan Keramik Pada Ruang Terapi Bermain

Dinding pada ruang terapi sensori dilapisi dengan busa sekelilingnya, sedangkan ruangan fisioterapi dan terapi bermain tidak menggunakan busa/ pelapis dinding. Material dinding pada ruang terapi baiknya dilengkapi foam wall ataupun gabus untuk membuat anak lebih aman dan nyaman saat terapi. Penggunaan acoustic wall juga dapat diterapkan untuk mengurangi kebisingan agar konsentrasi anak tidak terganggu. Selain material pada dinding dan lantai, material pada fasilitas terapi juga penting. Penerapan material pada alat terapi di Risantya belum cukup aman dengan anak, contohnya masih menggunakan fasilitas dengan tali yang tidak kuat untuk menopang anak (lihat Gambar 6). Dengan keterbatasan dana operasional, Risantya tidak sepenuhnya melapisi dinding material lembut atau sudutsudut tajam. Hal ini tidak sepenuhnya salah dan justru sengaja dilakukan oleh pihak Risantya. Tidak semua benda dibungkus dengan material lembut/lunak atau material lembut. Hal ini membantu anak $\mathrm{CP}$ untuk belajar mengidentifikasi material-material keras, seperti kayu, meskipun dalam bentuk yang lebih ramah, seperti HPL, multiplek, atau triplek sebagai pelapis. Anak-anak CP pun dilatih secara kognitif untuk belajar berhati-hati dalam menghadapi lingkungan sekitarnya.

Pemilihan material harus mengacu terhadap keselamatan dan kenyamanan anak CP dalam melakukan terapi. Hal ini terlihat bahwa pemilihan material menjadi sebuah hal yang penting dalam ruang terapi anak, khususnya pada anak CP.

\subsection{Low Physical Effort}

Antropometri dan ergonomi dalam ruang berpengaruh terhadap kenyamanan pergerakan anak CP. Keterbatasan gerak motorik kasar yang bervariasi menuntut desain interior juga arsitektur yang minim pergerakan. Kegiatan dan aktivitas anak CP saat terapi dapat dikelompokkan ke dalam kategori-kategori tertentu. Keterbatasan gerak yang perlu diantisipasi adalah anak yang menggunakan tongkat/alat bantu jalan dan kursi roda (Probowanti dan Saing, 2019).

Seluruh alat terapi dan fasilitas permainan disesuaikan dengan kebutuhan ukuran bagi anak-anak.
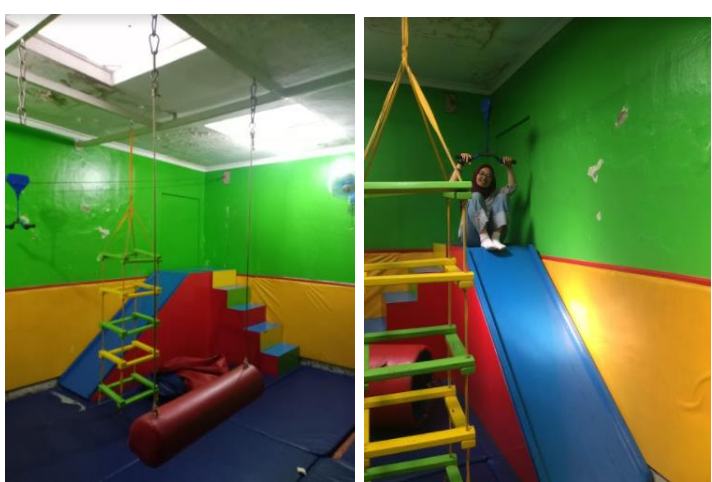

Gambar 9. Antropometri danErgonomi Alat

Tera pi Disesuaikan dengan Ukuran Anak-anak

Aksesibilitas dalam tempat terapi memiliki urgensi yang sangat tinggi. Aksesibilitas ini akan berpengaruh terhadap aktivitas dan prilaku anak CP. Aksesibilitas ini mencangkup sirkulasi dan ergonomi yang diterapkan pada tempat terapi. Mempertimbangkan perencanaan secara fungsional yaitu adanya jarak antar ruang atau bangunan yang relatif dekat dan sirkulasi aksesibilitas tanpa hambatan (Diono, 2014).

Tempat terapi Risantya mengaplikasikan sirkulasi linear di mana sirkulasi ini sudah baik diterapkan dalam tempat terapi karena tidak akan membuat pengguna, terutama anak CP kebingungan dalam aktivitasnya. Tetapi, beberapa sirkulasi yang ada di tempat terapi ini hanya mampu dilalui satu kursi roda yang dapat menghambat jalannya aktivitas yang ada. Akses pintu juga terlalu kecil yang hanya memuat satu kursi roda (satu daun pintu) dan pintu tidak 
memiliki fasilitas yang dapat mempermudah pengguna kursi roda untuk masuk dan keluar. Anak CP pengguna kursi roda, harus melepas kursi rodanya di luar ruangan dan melanjutkan dengan tongkat atau digendong ke dalam ruangan.

Dari hal ini maka perlunya sirkulasi yang dapat memuat minimal dua kursi roda untuk mempermudah akses menuju ruang terapi. Penerapan pintu yang memiliki dua daun pintu disarankan untuk mempermudah sirkulasi, serta penerapan pintu plat tendang juga disarankan agar pengguna kursi roda dapat dengan mudah membuka pintu. Hal lain yang mempengaruhi aksesibilitas adalah ergonomi. Tempat terapi ini belum menyediakan handrail/pegangan tangan untuk mempermudah anak yang memiliki kesulitan dalam berjalan. Penerapan handrail ini harus menyesuaikan standar ergonomi anak untuk mempermudah anak dalam menggunakannya. Mendesain sesuai dengan ergonomi juga akan membuat anak menggunakan upaya fisik yang rendah sehingga tidak membuat anak kelelahan dan kesusahan.

\subsection{Engaged Positively with Movement}

Terapi anak CP difokuskan pada latihan gerakan anggota gerak. Oleh karena itu, anak $\mathrm{CP}$ perlu didorong juga diberi semangat untuk mau bergerak. Hal ini dicapai dengan desain area terapi yang dapat meningkatkan keterikatan antara anak dengan lingkungannya. Pada setiap ruang terapi, ruangan ditata sedemikian rupa tanpa kolom/hambatan di tengah ruangan. Ruang didesain terbuka untuk memberikan kesan aman bagi anak $\mathrm{CP}$.

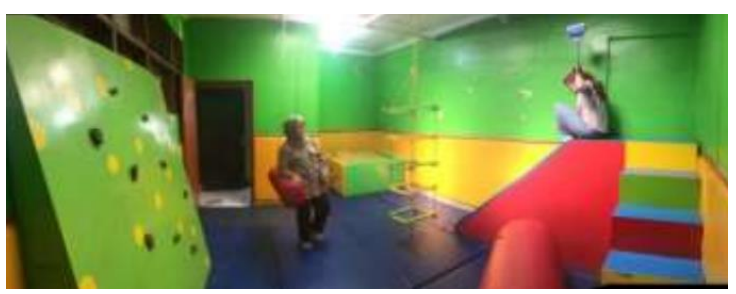

Gambar 10. Ruang Tera piSensori

Pada area bermain, ruang pun ditata sedemikian rupa agar fleksibel dan dapat dialihfungsikan dengan mudah untuk mewadahi kegiatankegiatan bersama, baik kegiatan sekolah maupun terapi (lihat gambar 11).

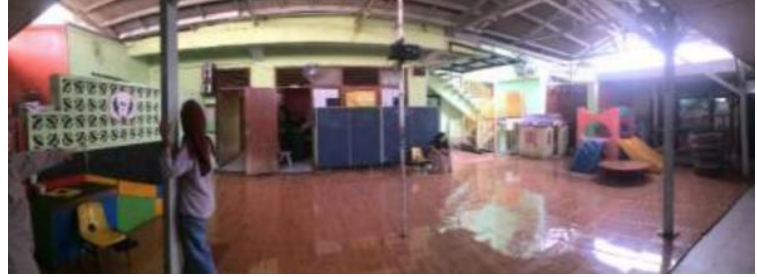

Gambar 11. Situasi Area Bermain Saat Dipersia pkan Untuk Kegia tan Bersama

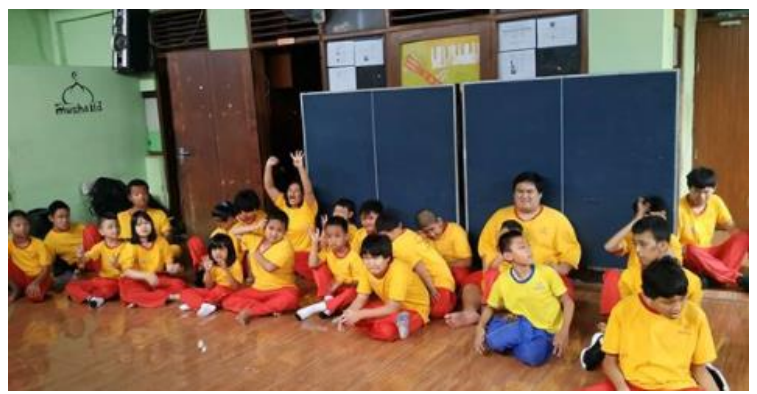

Gambar 12. Area Bermain Ketika Digunakan Kegiatan Bersama

Sumber: Risantya(2020)

Hal yang dapat ditingkatkan pada desain tempat terapi ini adalah penerapan bentuk elemen estetika seperti permainan bentuk geometris, pola, ataupun gambar. Elemen estetika hanya terlihat didominasi dari pengaplikasian warna. Mengacu pada Nielson dan Taylor (2011), ruang terapi dapat didesain dengan aplikasi bentukan yang dinamis dan gambar yang dapat merangsang dan menstimulis perkembangan anak selama proses terapi. Selain itu, bentuk dinamis ini dapat membuat anak lebih semangat beraktivitas dan bereksplorasi pada ruang terapi yang ada. Bentuk-bentuk dan gambar ini dapat diaplikasikan pada dinding lantai, maupun pada ceiling.

Permainan bentuk dan citra, rupa, dan wujud yang bervariasi secara umum muncul melalui alat-alat permainan yang digunakan untuk terapi ataupun alat-alat terapi itu sendiri. Keterbatasan yang ada di Risantya, sedikit banyak mengadaptasi alat-alat permainan anakanak pada umumnya untuk dijadikan alat terapi (lihat Gambar 13). Permainan ini cukup efektif dan sering digunakan anak-anak untuk bermain. Hal lain, alat/fasilitas terapi didesain sebagai alat-alat permainan seperti yang telah dilakukan oleh Risantya saat ini (lihat Gambar 6). Untuk permainan umum, dapat digunakan anak-anak secara mandiri. Sebagian alat-alat permainan yang dinilai berbahaya baru dapat dilakukan dengan pengawasan terapis. 


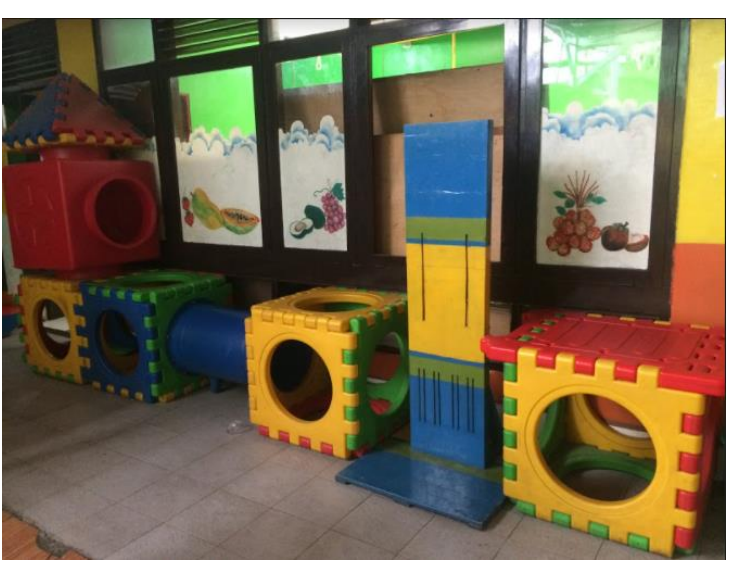

Gambar 13. Alat Permainan Dalam Melatih Gerak dan Aplikasi Mural pada Jendela Kaca

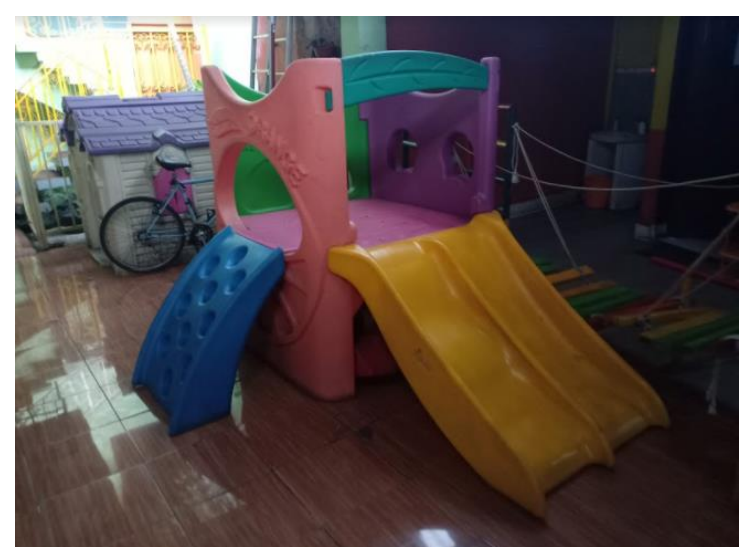

Gambar 14. Alat Permainan Modern yang Dia daptasi sebagai Alat Terapi

Engagement/ keterikatan antara anak CP dengan lingkungannya tidak lepas dari peran ketiga faktor yang telah disebutkan sebelumnya. Agar anak CP mau berlatih dan melakukan terapi, perlu kesinambungan empat faktor yang menjadi prioritas dalam perancangan tempat terapi bagi CP. Ruangan dapat didesain agar membangkitkan rasa keingintahuan anak untuk bereksplorasi.

Aplikasi warna-warna cerah dapat bermanfaat positif secara psikologi. Warna-warna seperti ini perlu ditelaah lebih lanjut atas dampaknya bagi anak-anak CP yang hipersensitif maupun hiposensitif. Penggunaan cahaya alami dapat membantu meningkatkan efek dari warnawarna yang dipakai. Untuk mengurangi intensitasnya, warna-warna cerah harus dikombinasi dengan penggunaan warna-warna netral, termasuk dalam bidang/bagian interior yang berada dalan jangkauan pandang anakanak.
Aplikasi material dan bentuk yang aman dan nyaman, memastikan anak-anak bebas dari cedera saat terapi ketika melakukan kontak/interaksi dengan lingkngan interior di sekitarnya. Area tertentu pada tempat terapi dapat didesain secara khusus untuk anak-anak belajar mengeksplorasi material atau pun benda-benda keras dan dengan permukaan agak kasar yang dapat menstimulasi dan tetap aman bagi anak. Penerapan tata ruang dengan sirkulasi yang tepat memudahkan anak CP dalam melakukan mobilitasi di ruang terapi maupun antar ruang terapi. Penggunaan antropometri dan ergonomi yang sesuai dengan anak-anak memudahkan mereka untuk beraktivitas tanpa mengeluarkan terlalu banyak tenaga.

\section{KESIMPULAN}

Berdasarkan penelitian terhadap kebutuhan aktivitas anak-anak CP, maka disimpulkan bahwa empat faktor menjelaskan konsep elemen interior yang optimal bagi tempat terapi anak dengan pendekatan terapi permainan, khususnya bagi anak CP. Pertama, konsep warna yang dihadirkan melalui permainan warna yang atraktif pada elemen interior dan atribut interior area terapi. Warna atraktif bukan berarti ruangan dipenuhi interior berwarnawarni tetapi melakukan kombinasi antar warna dan warna-warna cerah dengan warna netral. Kedua, konsep bentuk dan material yaitu setiap elemen interior dan furnitur didalamnya harus dibuat lebih aman untuk menghindarkan anak dari cedera/luka saat melakukan terapi. Ketiga, desain harus dapat memberikan kemudahan kepada anak ketika berada dalam ruangan dan beraktivitas didalamnya sehingga tidak menggunakan terlalu banyak usaha. Keempat, terakhir adalah memunculkan ikatan antara anak dengan lingkungan secara positif untuk menstimuli anak bergerak dan berinteraksi dengan lingkungannya. Hal-hal ini disatukan menjadi konsep A.B.L.E. yang merupakan singkatan dari Attractive colors, Bump, Bruise, and Pain-Free, Low Physical Effort, dan Engaged positively with movement.

Karena CP merupakan disabilitas yang memiliki kebutuhan tertinggi, maka konsep ini juga dapat diterapkan sebagai standar bagi tempat terapi anak berkebutuhan khusus lainnya. 
Perancangan fasilitas khusus seperti sekolah dan tempat terapi bagi anak berkebutuhan khusus memerlukan Kerjasama lintas disiplin ilmu dalam mewujudkan panduan desain yang baik dan optimal. Penelitian ini masih membuka peluang penelitian lanjutan mengenai efektivitas dan efisiensi keempat faktor tersebut bagi anak-anak $\mathrm{CP}$ juga anak berkebutuhan khusus lainnya.

\section{UCAPAN TERIMA KASIH}

Segenap tim penulis mengucapkan terima kasih kepada Universitas Telkom yang memberi dukungan dana dalam proses penelitian. Terima kasih juga disampaikan kepada pihak Risantya yang memberikan ijin untuk melakukan survey, pengamatan di lapangan, serta wawancara. Terima kasih secara khusus kepada Ibu Kusdarini, AMF, S.Pd., selaku kepala terapis di Risantya yang membantu dalam proses wawancara dan pengumpulan data di lapangan.

\section{REFERENSI}

Aflah, Saffanah Zhahirah \& Anisa (2020). Analisis Warna dan Bentuk terhadap Kemampuan Visual Anak Autis Pada Fasilitas Pendidikan. Jurnal LINEARS, 03(1).

AHP, Utomo. (2013). Cerebral Palsy Tipe Spastic Diplegy Pada Anak Usia Dua Tahun. Medula, 01(4), 25-34.

Astarina, Dinar Tri (2012). Little Boo Daycare And Preschool. Jurnal Tingkat Sarjana bidang Senirupa dan Desain FSRD ITB. 01(1), 1-8.

Astuti, Anggi Dwi. (2018). Penerapan Warna Pada Ruang Interior Anak Autis. Narada, Jurnal Desain \& Seni FDSK - UMB, 05(2), 33-44.

Atin, Supri., Himawanto Dwi Aries., \& Suryani, Nunuk (2018). Analysis Of Learning Desk Design For Children Mental Retardation At Extra Ordinary School Of Putra Mandiri, Cilacap. Indonesian Journal of Disability Studies (IJDS), 05(1), 145-151.

Bratton, SC. \& Dafoe, EC. (2016). Play Therapy. Encyclopedia of Mental Health, 03, 278-283.

Diono, Agus., Mujaddid., Prasetyo, Franciscus Adi. (2014). Bulletin Jendela Data Dan Informasi Kesehatan "Situasi Penyandang
Disabilitas”. Jakarta : Kementrian Kesehatan RI.

Elliot, A. J., \& Maier, M. A. (2014). Color psychology: Effects of perceiving color on psychological functioning in humans. Annual review of psychology, 65, 95-120.

Glover, G. dan Landreth, G. 2015. Child Centered Play Therapy. Handbook of Play Therapy (pp. 93-118). New Jersey : John Wiley \& Sons, Inc

Handoyo, A., Andrianawati, A., Pramesi, M. 2020. Tinjauan Desain Interior Pusat Terapi Anak Berkebutuhan Khusus (Cerebral Palsy) di Bandung. Naskah tidak diterbitkan, Universitas Telkom, Bandung.

Kristiawan, B., et al. (2016). Rehabilitasi Bersumberdaya Masyarakat Bagi Penyandang Difabel Di Sanggar Inklusi Mutiara Bunda. Jurnal Semar, 05(1), 7381.

Kusuma, Ayu Panji Wilda \& Budiono (2014), Desain Interior SLB-D Yayasan Pembinaan Anak Cacat Surabaya Sebagai Sarana Pendidikan Dan Terapi Berkonsep Green Design, Jurnal Sains Dan Seni Pomits, 02(1).

Moeloek, Abdul. (2018). Cerebral Palsy Tipe Spastik Quadriplegi Pada Anak Usia 5 Tahun. Medical Journal of Lampung University, 07(3), 186-190.

Nielson, Karla J. \& Taylor, David A. (2011). Interiors An Introduction "Design Principles, Elements, and Style". New York: McGraw-Hill.

Nurakhmi, Riksma., Santoso, Yoga Budhi., \& Pangestu, Prima Dea. (2019). Menemukenali dan Menstimulasi Anak Penyandang Disabilitas "Panduan Dasar Orang Tua, Keluarga, dan Pendamping”. Indonesia: Kementerian Pemberdayaan Perempuan dan Perlindungan Anak.

Probowati, Ajeng. \& Saing, Johannes H. (2019). Peran Fisioterapi Terhadap Kemajuan Motorik Pada Anak Dengan Cerebral Palsy. The Journal of Medical School (JMS) Talenta Publisher, 52(4), 191-198.

Purnomo, Didik., Kuswardani., \& Novitasari, Rizka. (2018). Pengaruh Terapi Latihan Terhadap Peningkatan Kemampuan Fungsional Pada Kasus Cerebral Palsy Spastik Diplegia. Jurnal Fisioterapi dan Rehabilitasi (JFR), 02(1), 1-8. 
Rea, B, Singgih E., dan Daryanto, T. 2013. Pusat Terapi Anak Dengan Gangguan Perilaku Sebagai Wadah Penanganan Kondisi Psikologis Dengan Pendekatan Arsitektur Perilaku Di Surakarta. Jurnal Arsitektura vol. 11 (1).

Sari, Sriti Mayang. (2011). Implementasi Konsep Desain Partisipasi Pada Interior Ruang Terapi Perilaku Anak Autis Dengan Menggunakan Metoda Aba/Lovass. Dimensi Interior, 09(1), 57-67.

Triani, Mia., et al (2018). Perancangan Klinik Terapi Khusus Anak Autis Di Kota Padang. Jurnal Teknik Sipil dan Perencanaan Universitas Bung Hatta, 02(2).

Widi, Narulita Anugrahing., Nirwansyah, Rullan (2013). Penerapan Aksesibilitas pada Desain Fasilitas Pendidikan Sekolah Luar Biasa. Jurnal Sains Dan Seni Pomits, 02(2).

Sakya, Kharista Astrini \& Santosa, Imam (2016). Desain Interior Lembaga Terapi Autis Di Kota Bandung, Indonesia. Proceedings of $2^{\text {nd }}$ International Conference On Creative Media, Design \& Technology (Reka2016). Available from : http://www.reka.usm.my/images/PAPER_ 27.pdf .[diakses pada: 08 Agustus 2020].

Susanto, Megawati \& Kristianto, Thomas Ari (2016). Desain Interior Fasilitas Pendidikan Yayasan Pembinaan Anak Cacat di Semolowaru Dengan Tema Modern Menggunakan Ide Bentuk Catur. Jurnal Sains Dan Seni ITS, 05(2), 53-58.

Whitfield, T. W., \& Whiltshire, T. J. (1990). Color psychology: A critical review. Genetic, Social, and General Psychology Monographs, 116(4), 385-411. 